\title{
Parental Determinism in the Swedish Strategy for Parenting Support
}

\section{Ulrika Widding}

Department of Education, Umeå University, Umeå, Sweden

E-mail: ulrika.widding@umu.se

This article analyses and problematises central assumptions in Sweden's National Strategy for Developing Parenting Support, a document that addresses children's deteriorating psychological health. The analysis was performed with Bacchi's (2009) approach to policy analysis. The results show how parental determinism is expressed; psychological ill health among school-aged children is described as an individualised problem caused by insecure parents, who are represented as the most important persons in a child's life and, therefore, are considered to be risk factors that require continuous support. Evidencebased parenting support programmes in particular are described as a central tool for improving parents' sense of responsibility and parenting skills. While the strategy aims to offer all Swedish parents support, it underlines ideals that have been related to gendered, middle-class notions of parenting. The issue concerning children's psychological health is problematised and discussed in relation to parental determinism, the risk society, equality, equity and psychological health.

Keywords: The National Strategy for Developing Parenting Support, psychological ill health, parental determinism, parenting support, policy analysis.

\section{Introduction}

Swedish parenting support relates to dominant discourse in a contemporary Western context in which parents' (failing) behaviours are thought to determine their children's health and future life, i.e. parental determinism (Furedi, 2008; Lee, 2014). This 'turn to parenting' (see Ostner et al., 2017: 6) is related to neoliberal ideas where every aspect of human life is connected to what is perceived as a constantly changing and all-embracing marketplace, and where individuals need to repeatedly examine, evaluate and change themselves (for example, their parenting skills) in order to be successful and happy (see, for example, McGee, 2005). These ideas have enabled an industry of what might be called self-help products, including literature, TV shows, seminars and therapy groups (see Crawford, 2004; Rapping, 1996). Many of these seemingly popular products deal with issues concerning family relationships. Following this international trend, some products, such as licensed parenting programmes, have been seen as new alternatives to existing welfare services and is an expression of a shifting focus in Swedish parenting support. Lundqvist (2015: 665) described this change in terms of 'the introduction of the idea of the autonomous parent and a re-orientation in public health', such as new forms of parenting support: Internet-based support, structured parenting programmes, and non-governmental organisations as providers of support. 
The currently scrutinising gaze on parents can partly be linked to more broadly spread ideas about risk consciousness and how risks associated to 'bad' parenting can be prevented if parents improve their skills according to expert advice (see Beck, 1998; Furedi, 2008). In the Swedish case, the changing forms of parenting support can also be traced back to economic cutbacks in welfare services that started in the 1980s, which were followed by neoliberal ideas that stressed the individual's responsibility and encouraged parents to choose various forms of parenting support according to their perceived needs (Gleichmann, 2004). Although ideas about the organisation of welfare services for families have shifted, Littmarck (2017) stated that there has been a political consensus about the importance of parenting support in Sweden. The National Strategy for Developing Parenting Support, which was unveiled in 2009 by the Swedish government, is a central document that sums up and expresses these general changes and principal ideas.

The document describe the Swedish campaign to improve well-being and prevent ill health among children and young people in which the government appointed the Public Health Agency of Sweden (Folkhälsomyndigheten ${ }^{1}$, 2014b) the mission to distribute 140 million SEK (approximately 12,7 million GBP) to a number of municipals to stimulate the development of local parenting support and to evaluate its effects. Parenting support is defined as 'an activity that gives parents knowledge on children's health, emotional, cognitive and social development and/or strengthens the parents' social network' ${ }^{2}$ (Socialdepartementet, 2009: 2). The overall goal is to offer all parents support in the course of the child's growth between zero to seventeen years of age. The first sub-target is to develop collaboration at a local level between players whose activities are aimed at parents, such as municipalities, county councils, faith communities, parents' associations etc. The second sub-target is to increase the number of venues for health promotion in order for parents to widen their social networks. The third sub-target is to increase the number of parenting support providers educated on health-promoting methods and universal evidence-based parenting support programmes ${ }^{3}$. Further, it is stated that parenting support should be based upon a gender equality perspective and a joint responsibility for parenting among mothers and fathers (Socialdepartementet, 2009: 3, 9).

The aim of this article is to analyse and discuss the strategy and some of its central assumptions by using Bacchi's (2009) problematising approach and the six related analytical questions. The 'problem' and the underlying assumptions (what Bacchi refers to as questions 1 and 2) are mainly described under the section The strategy for parenting support. The way in which the problem has been represented and produced (questions 3 and 6) are mainly illustrated in the next section, Governing good parenting. What is not problematised and possible effects of the way the problem is represented (questions 4 and 5) are mainly shown in the Discussion section.

\section{Governing good parenting}

According to the theoretical arguments from Foucault (1991: 100), the strategy for developing parenting support can be seen as a tool to improve children's health and secure the well-being of society's future citizens by offering parents support that works to monitor and govern them according to current family ideals (see Gleichmann, 2004; Daly, 2015). In line with this argument, Ohrlander (1987) claimed that Swedish child welfare, as we presently know it, is derived from the government's approach to infant mortality in the second half of the eighteenth century. Until this point, the role of controlling parents' 
upbringing of children, mainly children from the lower classes, had been a task for the state church and the clergy. However, societal changes, such as transforming into capitalistic forms of production, created new concerns for these children as possible workers in the future labour force. Ohrlander (1987) stated that this was the starting point of viewing childcare and child-rearing as a matter of health: caring for the child's body and good health, and the state's main tactics were to enlighten and discipline parents in the lower classes according to the growing medical expertise.

Ohrlander (1992) described how the following support to parents during the early 1900 s was concerned with poor families and especially unmarried mothers. One of the approaches was to arrange better housing and improved living standards for the working classes, but also to introduce them to bourgeois ideals of self-mastery and the importance of family life. Other strategies included the development of institutions, such as the Child Welfare Authority [Barnavårdsnämnden], with the task of locating neglected children and reforming the parents into taking responsibility for their children and improving their child-rearing skills. Furthermore, paediatricians became a highly influential professional group, providing scientific and rational answers to many of the problems related to what were regarded as unfit homes, leading to crime and moral perversion among children and young people (Ohrlander, 1992).

These strategies and ideas were later accompanied by internationally spread theories on attachment and bonding and the notion of the emotionally and psychologically vulnerable child that needs a close and strong relationship with an attentive adult (i.e. the mother) to care for the child's positive development. Such theories can be argued to precede parental determinism and they were picked up by, for example, Alva Myrdal, who introduced similar ideas about 'proper parenting' in Swedish family politics (Halldén, 1986). Myrdal held one of the first 'study circles' for parents in the early 1930s (Halldén, 1986) but the maternal and child health services came to be the main providers of parenting support from the 1930s onward, for example, courses for parents expecting their first child that were developed in the 1970s. Gleichmann (2004) argued that these services not only focused on informing parents (i.e. mothers) about child development and the best way to care for their children, but also supervised the parents and, if necessary, lectured them or notified the social authorities. Various reports about parenting support (see, for example, Föräldrastödsutredningen, 2008; Löthberg, 2007) show that it has been considered important to specifically reach (and supervise) the so-called at-risk groups and hard-to-reach parents: namely, immigrants (see Aurelius et al., 1986), first-time fathers (Premberg, 2011) and women described as having another native language than Swedish, who are smokers, unemployed or with little education (Fabian, 2008).

However, todays parental determinism entails the central assumption that every parent (not only parents in the at-risk groups) is obligated to reflect upon her or his parenting and how to improve their skills in order to secure their child's well-being and possibilities to live a future successful life (Furedi, 2008; Lee, 2014). Therefore, in order to be regarded as proper parents, it has been argued that today's parents are expected to 'keep themselves "up-to-date" with respect to the latest developments regarding good parenting (e.g. reading books, taking part in parenting courses)' (Ramaekers and Suissa, 2011: 197; see also Knijn and Hopman, 2015). There have also been claims that parenting support, such as parenting programmes (Peters, 2013; see also Dahlstedt and Fejes, 2013), entails governing technologies (for example exercises, moments to reflect upon one's parenting or informal talks about confessing your failure as a parent) that are very persuasive and 
hard to question as a parent. What parent could say she/he does not want the best for their child? In this sense might parenting support work as a rather powerful strategy to govern parents according to current family ideals about the responsible and 'good parent'.

\section{The 'what's the problem represented to be?' approach}

Bacchi's (2009) 'what's the problem represented to be?' approach ${ }^{4}$ is related to discourse analysis and aims to scrutinise taken-for-granted assumptions, their history and how these assumptions are related, as well as to pinpoint how central norms and values in a policy impinge upon on the way we think about the world and ourselves. Bacchi's point is that policies define problems (for example, children's ill health) by suggesting how to solve them (by improving parenting skills) but also prescribe how to govern people (i.e. parents) in their daily lives in order to solve a problem. The intention is to problematise the foundations and central premises (not the 'problem' itself) expressed in the policy and to discuss possible effects of the way the problem is represented. The goal is, however, not to provide 'the proper' solution to the focused 'problem' (Bacchi, 2009).

Bacchi's (2009) approach entails six analytical questions ${ }^{5}$ to examine discourses by identifying what is presented as the problem in a certain policy and what is assumed and taken for granted norms and ideals in this representation. This is done by investigating 'underlying conceptual logics' (Bacchi, 2009: 35), such as focusing on key concepts and categories expressed in the policy. Other important issues involve examining the genealogy of the problem representation, i.e. how it has been represented at different times and places and to explore possible competing discourses on the problem. Furthermore, it is essential to discuss possible effects of a specific problem representation in the way that subjectivities are constructed within a certain discourse and how this might affect individuals. A final issue is to describe what is not being problematised in a specific problem representation.

\section{The strategy for parenting support}

The National Strategy for Developing Parenting Support, the document published by Socialdepartementet 2009, is a description of the campaign to improve well-being and prevent ill health among children and young people, and is therefore the main material for the analysis. In order to understand some of the presuppositions expressed in this document the analytical questions deals with highlighting the main problem (i.e. the stated reason for making the strategy). In this case it is a 'concern' for the 'psychological health' among 'school-aged children and youth', since 'psychosomatic symptoms such as anxiety, depression, insomnia, fatigue, and headaches' have increased during the last decades and that '(a) large part of these stress related symptoms are more common among girls than among boys' (Socialdepartementet, 2009: 2, 4). The reason for the psychological ill health among children is clearly related to parents' (in-)abilities to care for their children. In fact, the very first sentence in the strategy, the preface signed by Maria Larsson, the appointed minister for the elderly and public health at that time (Äldre och folkhälsominister), concludes that: 'Parents are the most important persons in every child's life. Parents have, as no one else, the opportunity to give their children love, attention and values (...) and can influence the conditions for the child's physical but also psychological health.' (Socialdepartementet, 2009: preface). The notion that parents (or other caregivers) 'affect 
children's health', since they are the most important persons in their children's lives, and therefore have 'the main responsibility for their children's living conditions' is undoubtedly a foundational assumption in the strategy (Socialdepartementet, 2009: 4). Parents 'have a responsibility towards the child and the society', and are described as society's most important resource and protective factor when it comes to promoting children's health (Socialdepartementet, 2009: preface, 4-6).

Another central assumption is that today's parents are 'insecure and irresolute' from time to time and that they will encounter difficulties as the child develops and gets older, and due to changes in the child's environment (Socialdepartementet, 2009: 4, 7). Implicitly, this insecurity can lead to risk factor parenting, namely parents being 'neglectful or parents tolerant to norm-breaking behaviour such as alcohol or drug abuse or being involved in serious conflicts with each other or with their children' (Socialdepartementet, 2009: 6). In this sense, insecure parents are represented as the more specific problem in the strategy. Parents, or the family, are thus defined as the most significant risk factor when it comes to children's health (Socialdepartementet, 2009: 6). In relation to this assumption it is also stated that there is no way to predict which children will develop problems later in life (i.e. in which families there might be problems) so the best solution is defined as a preventive approach, in the form of a universal, general support for all Swedish parents (Socialdepartementet, 2009: 2, 4, 6, 9).

Although the strategy declares that parenting support should be universal (offered to all parents) but optional and 'not a compulsory activity for parents' (Socialdepartementet, 2009: 9), it is however stated that it is important to attract unmotivated or uninterested parents (presumably risk factor parents). Therefore, the approach is to welcome all sorts of parents, 'no matter if you are a mother or father, single parent, if you have a foreign background or if you are a parent to a disabled child' (Socialdepartementet, 2009: 7). The strategy is also to increase the number of local venues, such as maternity clinics, open preschools, family centres, libraries, cafés, etc., in order to attract all sorts of parents (Socialdepartementet, 2009: 3, 5).

The overall goal of the strategy is to support parents in 'the process where parents engage in their child and where the parent gives the child physical and emotional care, nurture and protection' (Socialdepartementet, 2009: 4). More specifically, the main solution to the problem of psychological ill health is implicitly to support parents to become well-functioning parents. This is described as having the ability to create 'a close and trustful relation between children and parents' and to be 'stable parents with a low level of conflict, [that can construct] a balance between distinct boundaries and love and warmth, and parents that give the child attention for positive behaviour' (Socialdepartementet, 2009: 6). In order to improve parents' skills (i.e. to make parents well functional), it is frequently stressed that parenting support should be evidence-based, such as structured parenting programmes (Socialdepartementet, 2009: 3, 7, 9, 15, 16). However, it is also argued that parents need support to trust their own capabilities and help to promote their self-confidence (Socialdepartementet, 2009: 5, 7, 11).

\section{Discussion}

In contemporary Sweden, as well as other Nordic countries, political ideas on the welfare state and the collective society have partly been replaced by liberal ideas that imply that the state should decrease its influence over individuals' everyday lives (see Anttonen 
et al., 2012). However, the state must still protect general interests, such as growing costs for welfare services associated to children's psychological ill health and at the same time safeguard that children become productive citizens in the future. Parenting support is therefore about seeking 'to control, supervise and/or guide parental practice' (especially among the irresponsible and at-risk group of parents), but at the same time adjust to families' desire for 'privacy and [their] resistance to the state's intrusion and paternalism' (Martin, 2015: 617). Thus, parenting support cannot be compulsory and forced upon parents, but must be presented as an offer with an implicit appeal to their willingness to be(-come) good parents. The emphasis on parents' responsibilities (i.e. parental determinism) in the Swedish strategy for parenting support is therefore consistent with Bacchi's (2009: 134) argument about 'responsibilisation and self-regulation' as a way of directing the question of health to be about individuals choosing the right lifestyle (or proper parenting). Responsibilisation is consequently about governing parents to freely choose to improve their abilities for the good of their children, but also to save costs for the welfare state according to the assumption that good parenting can prevent psychological ill health.

While it is psychological ill health among children that is represented as a crucial problem in Sweden, similar to the Netherlands (Knijn and Hopman, 2015: 646), it is worth noting that, in England, parenting support is often associated with youth problems such as delinquency, anti-social behaviour and school failure (Gillies, 2005). With the focus on psychological (ill) health, the Swedish strategy relies heavily on psychiatric and psychological research (see Föräldrastödsutredningen, 2008) that mainly relates children's psychological health to parents' ability to create a good parent-child relationship. Thereby, the strategy's basic assumption about parents' responsibility to improve their abilities is that parenting support can somewhat inoculate children against psychological ill health (see Bacchi, 2009: 128), when the problem seems to be more complex. It has, for example, no references to discussions of how children's health relate to their school experiences or their involvement in leisure time activities - although it is said to be primarily school-aged children and youth that suffer from psychological ill health.

As described earlier, the strategy represents parents as insecure and in need of support throughout the whole period in which their children grow up. The strategy also contends that all families are presumably at risk - you can never predict where, and when, there might be problems - and this presupposition has the effect that family life might be understood as somewhat hazardous. Thereby the strategy works to construct different risks (see Ramaekers, 2005; Rasborg, 2012) associated with family life in order to encourage (or perhaps scare) parents to become more aware and responsible for their parenting. In this sense, parenting support, such as parenting programmes, might increase parents' insecurity and make them more dependent upon support (see Furedi, 2008). Hence, it is important to investigate how parents relate to expertise and parenting support and how they think these components affect their parenting. It is also worth noting that Sihvonen (2016) concludes that the specifics of Finnish parenting support is the focus on encouraging parents' own knowledge and expertise, which points to the importance of further studies on the variations and similarities in parenting support in different national contexts.

Although the strategy underlines the importance of including all parents in equal participation, available statistics related to the government's campaign show that the various parenting programmes mainly attracted women, who constituted 88.7 per cent 
of the participants (Löfgren et al., 2017: 27, see also Alfredsson and Broberg, 2016). This outcome contradicts the ambition to offer parents support that emanates from 'a joint parental responsibility and a gender equal parenthood' (Socialdepartementet, 2009: 9, 16) and it has previously been argued that parenting support tend to reinforce traditional ideals of motherhood since it underlines women's parental responsibilities (Clarke, 2006; Hey and Bradford, 2006). Such problems have been related to instrumental and genderblind parenting support which have also been noted in a broader European context (Daly, 2013; Martin, 2015). Gender-blind parenting can also be argued to be an effect of parental determinism and the focus on the individual parent with no regard to gendered power relations and parenthood.

It has also been shown that within a sample of parents from the 'general population' taking part in parenting programmes during the campaign, 92.6 per cent of the mothers and 93.5 per cent of the fathers stated Sweden as their origin, and 71.6 per cent of the mothers and 56.4 per cent of the fathers had an education above high school (Löfgren et al., 2017: 27). This is in line with international research and other surveys on Swedish parenting support programs (Alfredsson and Broberg, 2016). Such outcomes could, for example, imply that parents with higher education are more insecure and therefore more willing to comply to governing advice about their parenting, and this would be an interesting question to pursue. However, several researchers have also shown how intensive parenting ideals (being 'child-centred, expert-guided, emotionally absorbing, labor intensive, and financially expensive' (Hays, 1996: 8 italics original; see also Forsberg, 2009)) influence parenting support and tend to represent ethnic minorities and/or working class families as problematic (Gillies, 2005, 2007; see also Tilsen, 2007; Lee, 2014). Thus, the above statistics might also indicate that underlying racialised white and middle-class norms of parenthood repel other groups of parents from parenting support since they are implicitly represented as problematic and/or at risk.

Since the national strategy for developing parenting support was launched, has the question of psychological ill health become even more central in general and political debate. For example, national studies on school-aged children's perceptions of their health show that the older the girls get, the more often they experience psychological or somatic ill health compared to boys (in some cases, almost twice as often as boys), an increase from 47.9 per cent of the 15-year-old girls in 2009/2010, to 57 per cent in 2013/2014 (Folkhälsomyndigheten, 2017; see also Folkhälsomyndigheten, 2014c). Similar patterns can be seen among Swedish adults where statistics show that stress-related ill health increased by 119 per cent in Sweden from 2010-2015 (Försäkringskassan, 2016). Women constituted 73 per cent of the total amount of diagnoses of psychiatric ill health in 2015. The question is what these statistics possibly say about parents/adults as the solution to children's psychological ill health. Is it so, that parental determinism and the emphasis on parents' responsibilities might increase the pressures on parents in everyday life, and presumably for those mothers who are the overall accountable for their children's health? The governing strategy in itself, i.e. the call for parents to scrutinise, constantly evaluate and reflect upon how to improve their parenting skills, in a society that already has high demands on self-governance and performance, can probably make the most stable parent uncertain and put under pressure. Parents who choose not to engage in such demands might be categorised as irresponsible and bad parents, which would work as another kind of stress in their daily life. Moreover, parental determinism and the responsibilisation of the individual parent mean that social power relations, and the intersections of, for example, 
gender, social class and ethnicity turn out to be unproblematised when it comes to understanding the complexity of the various frameworks that condition the psychological health of both adults and children. Thereby, considering that the statistics point to a growing problem of psychological ill health among both children and adults, with a related increase of costs for the welfare society, it seems that the 'problem' represented to be in this specific strategy is still unsolved. If politicians and policymakers want to redefine the 'problem', they need to be aware of how new strategies and policies will govern the way we think about issues such as 'health' and 'parenting', and how this might affect people differently in relation to social power relations.

\section{Acknowledgements}

I wish to acknowledge the help and advice provided by the guest editors, Astrid Ouahyb Sundsbø and Ella Sihvonen, and the anonymous reviewers.

\section{Notes}

1 Previously called Folkhälsoinstitutet.

2 The author has translated all the following citations from the strategy.

3 Some of these parenting programs are internationally known, for example, International Child Development Programme (ICDP), Active Parenting, Triple-P, Cope and Connect, but some were developed in Sweden, such as Familjeverkstan, ABC and Komet (Folkhälsomyndigheten, 2014a). Many of the programs have been running both before and after the specific campaign to develop parenting support.

4 Daly's (2015) analytical framework for investigating parenting support policies includes similar analytical questions.

5 The analysis was done as 'a more integrated form of analysis', which means that the six analytical questions were not analysed separately since they are interrelated (Bacchi, 2009: xxi).

\section{References}

Alfredsson, E. K. and Broberg, A. G. (2016) 'Universal parent support groups for parents of adolescents: which parents participate and why?', Scandinavian Journal of Psychology, 57, 177-84.

Anttonen, A., Häikiö, L. and Stefánsson, K. (eds.) (2012) Welfare State, Universalism and Diversity, Cheltenham: Edward Elgar.

Aurelius, G., Blondell, I., Gustafsson, I., Höjer, B., Kivisaari, H., Lagerstedt, E., Olin-Lauritzen, S., Sachs, L. and Weidenmark, E. (1986) Föräldrautbildning i ett mångkulturellt samhälle - FIMS Kulturmöten i vården, Stockholm: Stockholms läns landsting.

Bacchi, C. (2009) Analysing Policy: What's the Problem Represented to be?, Frenchs Forest: Pearson.

Beck, U. (1998) Risksamhället: På väg mot en annan modernitet, Göteborg: Daidalos.

Clarke, K. (2006) 'Childhood, parenting and early intervention: a critical examination of the Sure Start national programme', Critical Social Policy, 26, 4, 699-721.

Crawford, M. (2004) 'Mars and Venus Collide: a discursive analysis of marital self-help psychology', Feminism and Psychology, 14, 1, 63-79.

Dahlstedt, M. and Fejes, A. (2013) 'Family makeover: coaching, confession and parental responsibilisation', Pedagogy, Culture and Society, 22, 2, 169-188.

Daly, M. (2013) 'Parenting support: another gender-related policy illusion in Europe?', Women's Studies International Forum, 46, 223-230.

Daly, M. (2015) 'Parenting support as policy field: an analytic framework', Social Policy and Society, 14, 4, 597-608. 
Fabian, H. (2008) Women who do not Attend Parental Education Classes during Pregnancy or after Birth, Stockholm: Karolinska institutet.

Folkhälsomyndigheten (2014a) Föräldrar spelar roll. Vägledning i lokalt och regionalt föräldrastödsarbete, https://www.folkhalsomyndigheten.se/contentassets/17c2137a091b4b12a42d43e48cb6827d/ foraldrar-spelar-roll-vagledning-i-lokalt-och-regionalt-foraldrastodsarbete.pdf [accessed 10.05.2017].

Folkhälsomyndigheten (2014b) Slutredovisning av uppdrag kring ett utvecklat föräldrastöd. 3607/20141.1.1, https://www.folkhalsomyndigheten.se/documents/livsvillkor-levnadsvanor/barn-unga/ foraldrastod/Slutrapport\%20Utv\%C3\%A4rdering\%20o\%20utveckling\%202014.pdf [accessed 27.03.2017].

Folkhälsomyndigheten (2014c) Skolbarns hälsovanor i Sverige 2013/14, https://www. folkhalsomyndigheten.se/contentassets/fbcbd76d2cae4fc0981e35dddf246cf0/skolbarnshalsovanor-sverige-2013-14.pdf [accessed 29.11.2017].

Folkhälsomyndigheten (2017) Psykiska och somatiska besvär bland skolelever, https://www. folkhalsomyndigheten.se/folkhalsorapportering-statistik/folkhalsans-utveckling/halsa/psykisk-ohalsa/ psykiska-och-somatiska-besvar-bland-skolelever/ [accessed 29.11.2017].

Forsberg, L. (2009) Involved Parenthood: Everyday Lives of Swedish Middle-Class Families, (Doctoral thesis, Department of Child Studies, Linköping University), Linköping: Linköping University.

Foucault, M. (1991) 'Governmentality', in G. Burchell, C. Gordon and P. Miller (eds.), The Foucault Effect, Studies in Governmentality, Chicago: The University of Chicago Press, 87-104.

Furedi, F. (2008) Paranoid Parenting: Why Ignoring the Experts may be Best for your Child, London: Continuum.

Föräldrastödsutredningen (2008) Föräldrastöd - en vinst för alla, Betänkande av utredningen nationell strategi för samhällets stöd och hjälp till föräldrar i deras föräldraskap, SOU 2008: 131, Stockholm: Fritzes.

Försäkringskassan (2016) Sjukskrivning för reaktioner på svår stress ökar mest, Psykisk ohälsa, Korta analyser 2016:2, https://www.forsakringskassan.se/wps/wcm/connect/41903408-e87d-4e5e-8f7f90275dafe6ad/korta_analyser_2016_2.pdf?MOD=AJPERES\&CVID= [accessed 03.27.2017].

Gillies, V. (2005) 'Meeting parents' needs? Discourses of "support" and "inclusion" in family policy', Critical Social Policy, 25, 1, 70-90.

Gillies, V. (2007) Marginalised Mothers: Exploring Working-Class Experiences of Parenting, London, New York: Routledge.

Gleichmann, L. (2004) Föräldraskap mellan styrning och samhällsomvandling: En studie av syn på föräldrar och relation mellan familj och samhälle under perioden 1957-1997, Stockholm: HLS Förlag.

Halldén, G. (1986) Alva Myrdals föräldracirkel: En pedagog beskriven via sina anteckningar. Forskningsrapport nr 32, Stockholm: Stockholms universitet, Pedagogiska institutionen.

Hays, S. (1996) The Cultural Contradictions of Motherhood, New Haven and London: Yale University Press.

Hey, H. and Bradford, S. (2006) 'Re-engineering motherhood? Sure Start in the community', Contemporary Issues in Early Childhood, 7, 1, 53-67.

Knijn, T. and Hopman, M. (2015) 'Parenting support in the dutch "participation society"', Social Policy and Society, 14, 4, 645-56.

Lee, E. (2014) 'Introduction', in E. Lee, J. Bristow, C. Faircloth and J. Macvarish (eds.), Parenting Culture Studies, Hampshire, New York: Palgrave Macmillan.

Littmarck, S. (2017) Barn, föräldrar, välfärdsstat: Den politiska debatten om föräldrautbildning och föräldrastöd 1964-2009, Linköping: Linköpings Universitet.

Lundqvist, ^.. (2015) 'Parenting support in Sweden: new policies in old settings', Social Policy and Society, $14,4,657-68$

Löfgren, H. O., Petersen, S., Nilsson, K., Ghazinour, M. and Hägglöf, B. (2017) 'Effects of parent training programmes on parents' sense of competence in a general population sample', Global Journal of Health Science, 9,7, 24-34. 
Löthberg, M. (2007) Gott föräldraskap kräver kompetenta föräldrar - en studie om hur maktrelationer mellan föräldrar och samhälle framträder $i$ en statlig text om föräldrastöd, D-uppsats nr 2007:10, Pedagogiska institutionen, Uppsala universitet, Uppsala: Uppsala universitet.

Martin, C. (2015) 'Parenting support in France: policy in an ideological battlefield', Social Policy and Society, 14, 4, 609-20.

McGee, M. (2005) Self-Help Inc.: Makeover Culture in American Life, Oxford: Oxford University Press.

Ohrlander, K. (1987) När barnet fick en kropp: Om statsmakternas försök att ändra folkliga traditioner inom barnavården från 1700-talets mitt till 1900-talets början, Stockholm: Institutionen för pedagogik, Högskolan för lärarutbildning i Stockholm.

Ohrlander, K. (1992) I barnens och nationens intresse: Socialliberal reformpolitik 1903-1930, Stockholm: Almqvist \& Wiksell.

Ostner, I., Betz, T. and Honig, M-S. (2017) 'Introduction: parenting practices and parenting support in recent debates and policies', in T. Betz, M-S. Honig and I. Ostner (eds.), Parents in the Spotlight: Parenting Practices and Support from a Comparative Perspective, Opladen, Berlin, Toronto: Barbara Budrich Publishers.

Peters, E. (2013) 'The weight of my words; the role of confession and surveillance in parenting programmes', Journal of Social Welfare and Family Law, 34, 4, 411-24.

Premberg, Å. (2011) Förstagångsfäders upplevelser av föräldrautbildning, förlossning och första året som far, Göteborg: Göteborgs universitet.

Ramaekers, S. (2005) 'Educational support, empowerment, and its risks: the correct voice of support?', Educational Theory, 55, 2, 151-63.

Ramaekers, S. and Suissa, J. (2011) 'Parents as 'educators': languages of education', pedagogy and 'parenting", Ethics and Education, 6, 2, 197-212.

Rapping, E. (1996) The Culture of Recovery: Making Sense of the Self-Help Movement in Women's Lives, Boston: Beacon Press.

Rasborg, K. (2012) "“(World) risk society" or "new rationalities of risk"? A critical discussion of Ulrich Beck's theory of reflexive modernity', Thesis Eleven, 108, 1, 3-25.

Sihvonen, E. (2016) 'Early interventionist parenting support: the case study of Finland', Families, Relationships and Societies, https://doi.org/10.1332/204674316X14552878034703.

Socialdepartementet (2009) Nationell strategi för ett utvecklat föräldrastöd: En vinst för alla, Stockholm: Socialdepartementet.

Tilsen, J. (2007) 'We don't need no education', Journal of Progressive Human Services, 18, 1, 71-87. 